\title{
On the Role and Place of Bank Operations in Current Development of the Russian Securities Market
}

\author{
Natalya A. Kovaleva ${ }^{1}$ \\ 1 Department of Banks \& Bank Management, Financial University under the Government of the Russian \\ Federation,School of Management, Moscow, Russian Federation \\ Correspondence: N. A. Kovaleva, Department of Banks \& Bank Management, Financial University under the \\ Government of the Russian Federation, Moscow, Russian Federation. Tel: 7-495-615-72-75. E-mail: bibm@fa.ru
}

\author{
Received: March 11, 2015 Accepted: April 10, 2015 Online Published: May 25, 2015 \\ doi:10.5539/res.v7n10p114 URL: http://dx.doi.org/10.5539/res.v7n10p114
}

\begin{abstract}
This article is concerned with a survey of the main directions of Russian banks activities in the securities market. It mentions types of bank operations, statistics on the volume of operations, as well as it considers stages of development of the Russian securities market which defined its modern structure and dominant position of banks.
\end{abstract}

Keywords: banks, securities, the Russian stock market

\section{Introduction}

Securities market plays an important part in the economical processes which take place in Russia. Its main aim is to provide flexible input-output reallocations of investments, to create the most effective stream of domestic and foreign investments into Russian enterprises, to establish all necessary conditions under which the savings are encouraged and transformed into investments especially during financial crisis.

Galloping development of the Russian securities market has defined its main contradiction, that is the contradiction between artificial creation of market structure by authorities, mostly be means of foreign special purpose credits, on the one side, and natural formation of market entities under conditions of gradually developing market economy, on the other side. In this regard, prior to analysis of the current state of the Russian securities market, we need to make a short stop on characteristic features of the main stages of development of the Russian securities market and their affect on the formation of the market structure.

The process of establishing of the market structure in Russia takes its origin in 1990s when "the securities market boom" produced a huge amount of securities exchanges. In the period starting from the middle of 1990 till 1991 there appeared 800 establishments of that kind. (Galkin \& Komov, 1998) Actually securities exchanges appeared prematurely, before objective preconditions and necessities in such services came into view, more importantly, before securities started their way to the Russian market. Securities exchanges which usually appear at the final stage of national or local securities market formation, turned out to be the first component of the Russian market structure while this structure is required to provide full circulation of securities and other types of financial instruments.

Next stage is the stage of privatization. During this period securities exchanges place their stakes on the project on State property which started in autumn of 1992. It refers us to so-called "vouchers" which mean privatization checks issued in 1992. About 160 million vouchers were issued then. (Galkin \& Komov, 1998) They occurred to be the only publicly traded securities. The main distinctive characteristics of vouchers were as follows: bearer's nature of such securities, issue of the mentioned securities for cash purposes and the only redeem ability of such securities limited to being instruments of payment in privatization deals. The abovementioned features as well as massive issue of them at that time made vouchers very attractive for speculative purposes. In fact, the decision of securities exchanges in favor of vouchers and quasi-securities was a result of the stock crisis which in its turn was caused by incorrect sequence of events in development of the Russian market structure, which began with establishment of securities markets. During this period active trade of different types of quasi-securities issued by such companies as MMM, RDS and the like was in full blossom. Never the less, the abovementioned stage had also a positive effect on the development of the Russian securities market. Independent dealer and broker 
companies as well as departments of commercial banks working in the same directions have gained their first experience in voucher trade. (Anesyants, 1998)

Public securities market which started first trading in May 1993 takes a special place in the structure of the Russian securities market. Its vigorous growth in 1993-1995 provided guidelines not only for the stock market but for financial market in Russia in general in many ways. By the end of 1995 public securities market with its GKO-OFZ (Note 1) came up to global level in Russia in terms of trading volume, technical basis and legislation. While analyzing the role of public securities market in the development of the securities market in general, it is necessary to start with appearance of the first in Russia, single package combining trading, settlement and depositary systems.

Russian corporate shares market took its start at the end of the privatization stage, but it officially its appearance dates back to 1995 when considerable amount of foreign capital made its way to the market. First of all, it is connected with opening of Russian Trading System (RTS) which at the present moment is one of the leading securities market makers in Russia dealing with securities of joint stock companies.

Credit institutions took a dominant position among securities market participants due to the historical factors of development of the Russian securities market, such as creation of high tech RSM (Note 2) by authorities for national loans and appearance of natural segment of corporate securities. (Burakov, 2014a; 2014b) The reason is that banks have all kinds of necessary resources: funds, qualified personnel, vaults, procedure of transaction processing and control, technical support, facilities. Credit institutions can provide their clients with full package of services on the securities market. That's why it reasonable to place a stake on credit establishments while considering the development of the securities market structure.

The special thing about Russian banks being securities market participants is that they trade following general rules for all participants, and besides, they are to follow additional rules set by the Central Bank of Russia.

Till the present moment three directions of bank activity in the securities market were taken into consideration:

- Issuing function (issue of its own securities);

- Investment in securities of other companies;

- Special activity which appeared in Russia in 1990s and is connected with provision of professional services according to the license of professional securities marker participant (Note 3).

Galloping development of the Russian securities market produced one more business for credit institutions - services on the securities market. This group of service includes non-licensed ones, such as loans secured by stock, loans for stock purchase, and business of settlement agent of an issuer, management of issue and circulation of different types of securities of an issuer. (Burakov, 2014c) This group also involves bank operations on the securities market known as investment banking, including IPO and preparation for IPO, underwriting, issue and circulation of corporate bonds and etc.

As the result, bank operations on the securities market at the present stage can be divided into four groups reflecting different functions of banks on the securities market. Each group includes a wide range of various operations regarding the circulation of securities as well as enforcement of rights of stockholders. Let us give more detailed description to each group.

Banks activity as issuers implies operations on emission (issue) of their own securities: shares, bonds, certificates of deposit (saving certificates), promissory notes, as well as operations and actions on enforcement of investors' rights certified by securities issued by banks: payment of interests and dividends; repayment on debt securities at maturity; arrangement of terms at which shareholders can take part in bank management, including arrangement of general meetings of shareholders, reports on issuing bank. $\boldsymbol{k}$ activisetailed description to each of the grouptions which participant ntionin.

Speaking of volumes of bank operations in this field in recent period, it should be mentioned that capitalization of banking system in the Russian Federation is in constant progress. Thus, authorized share capital of the Russian credit institutions was equal to 1341425 million rubles on the 1st of January, 2013, it was 1562615 million rubles on the 1st of January, 2014. By increasing of their own capital, including increasing of charter funds, banks are eager to reach the level of 300 million rubles which will be required by law (Bank of Russia).

The issue of certificates of deposit (saving certificates), on the contrary, can be characterized as increasing in 2013-2014. Thus, the fund of certificates of deposit issued by banks was equal to 4070 million rubles on the 1 st of January, 2013, and it was 5900 million rubles on the 1st of September, 2014; the fund of saving certificates was equal to 228380 million rubles on the 1st of January, 2013 and 360100 million rubles on the 1st of September, 
2014. At the same period the sum of issued bonds increased from 1037410 million rubles on the 1st of January, 2013 up to 1143900 million rubles on the 1st of September, 2014. Banks are in constant search of ways to increase their resources, especially by means of long terms instruments, thus, bonds with maturity period being more than 3 years keep the dominant position in the structure of bonds. The issue of promissory notes were equal to 1149310 million rubles on the 1st of January, 2013 and 891600 million rubles on the 1st of September, 2014. (Bank of Russia)

Banks activity as investors implies operations on sale and purchase of securities; gaining credits secured by purchased securities; operations on enforcement of rights which belong to investing bank and are certified purchased securities: receipt of interests, dividends and repayments on debt securities at maturity; participation in management of the issuing joint stock company; participation in bankruptcy procedures either as the creditor or as the shareholder; receipt of the relevant share in the property of the company in case of its liquidation. Banks also deal with operations with derivatives (futures and forward contracts, options), which can be divided into speculative and hedging.

Debt securities (except promissory notes) take the first place in the structure of investments made by commercial banks. In 2013-2014 such investments were gradually increasing: investment portfolios of banks were estimated as 5265100 million rubles on the 1st of January, 2013 and 6410200 million rubles on the 1st of September, 2014. Investments in equity securities (shares) were also growing in 2013-2014 (579 400 million rubles on the 1st of January, 2013 and 1372100 million rubles on the 1st of September, 2014). (Bank of Russia)

\section{Banks Activity as Professional Securities Market Participants}

Provision of certain services on the Russian securities market is regulated in a special way. It refers to the operations known as professional activity in the securities market. Russian legislation, for example Federal law "On Stock Market" defines the following as professional activity in the securities market: broker's business, dealer's business, securities management, clearing, depositary's business, keeping the register of securities holders, settlement of trade in the securities market.

It a historical fact that credit institutions obtain licenses of professional participants and perform the following kinds of professional activity in the securities market: broker's business, dealer's business, stock management, depositary's business, clearing (it is typical of non-bank credit institutions). Keeping the register of securities holders can not be combined with other kinds of professional activities in the securities market. In this regard only professional participants of the securities market which are called the registrars can deal with this kind of operations, and such activity is the only one for them. Banks which were highly involved in registrar's activity before the Federal law "On Securities Market" came into force in 1996, had to quit it. Credit institutions do not deal with such activity as settlement of trade in the securities market, due to the fact that this kind of professional activity in the securities market belongs to stock exchanges. It is necessary to point out such striking peculiarity of the Russian securities market as dominant position of banks among professional participants. Thus, 415 of 840 participants with dealer licenses are banks, 413 of 836 participants with broker licenses are banks, and 351 of 588 depositories are credit institutions (Bank of Russia). Therefore, statistics proves that more that a half of the securities market makers are banks, when referred to broker's and dealer's activity, and about one third if referred to depository activity.

Bank operations in connection with services in the securities market include providing credits for stock purchase and credits secured by stock; providing bank guarantees in regard to issues of bonds and other securities (for example, residential certificates); providing services of settlement agents of an issuers, maintaining of accounts of the participants of the securities market and dealing with settlement at the close of trading in the securities market, etc.

The demand on bank operations connected with services in the securities market appeared with establishment of RSM. Settlement at the close of trading on the basis of RSM can be an outstanding example of the abovementioned. But these operations have obtained their rapid and full-scale popularity only in recent years. Banks specializing in this kind of activities, so-called investment banks, came into view. During the last years we can witness IPO "boom" of various companies and banks in the Russian securities market as well as on the foreign stock exchanges in regards to the issue of corporate bonds. Such hands-on investors are Sberbank, Raiffaisen Bank, Rosbank, VTB, Alfa-Bank, etc.

\section{Conclusion}

Summarizing the results, it necessary to mention that development of economy and financial markets at the present period, their globalization create new needs of the clients in financial services. There come specific activities and 
operations which are non-banking in their nature. Credit institutions become multipurpose instrument in the monetary and financial markets. These tendencies did not pass by the Russian securities market, thus in addition to classical banks operations such as the issue of their securities and purchase of securities from the third parties, there appeared two more current directions, and they are professional activity and the newest one-operations in connection with services in the securities market. The latest produced new kinds of banks-investment banks.

\section{References}

Anesyants, A. S. (1998). The basis of the securities market functioning (p. 368). EBM-Kontur.

Bank of Russia. (2013). The Bulletin of Banking Statistics, 2, 237.

Bank of Russia. (2014). The Bulletin of Banking Statistics, 10, 257.

Burakov, D. V. (2014a). Credit Cycles \& Debt Restructuring: Refining Theoretical Flaws. Review of European Studies, 6(4), 1-11. http://dx.doi.org/10.5539/res.v6n4p1

Burakov, D. V. (2014b). Do Methods of Estimation Affect Credit Risk Osccillations? Mediterranean Journal of Social Sciences, 5(20), 114-120. http://dx.doi.org/10.5901/mjss.2014.v5n20p114

Burakov, D. V. (2014c). How to Measure Herd Behavior on the Credit Market? Mediterranean Journal of Social Sciences, 5(20), 516-521. http://dx.doi.org/10.5901/mjss.2014.v5n20p516

Civil Code of the Russian Federation (Part I and Part II), Russian Civil Code, Russian Legislation.

Demirguc-Kunt, A., Feyen, E., \& Levine, R. (2011).The Evolving Importance of Banks and Securities Market. Policy Research Working Paper. World Bank.

Federal Law 39-FZ of April 26, 1996 “On Securities Market”.

Federal Law 395-1 of December 2, 1990 "On Banks and Bank Activity".

Federal Law 208-FZ of November 24, 1995 “On Joint Stock Companies”.

Galkin, I. V., Komov, A. V., Chizhov, S. D., \& Pizov, Y. S. (1998). Securities markets in the USA and in Russia. In Formation and regulations (p. 222). M.: Economics.

Levine, R., \& Zervos, S. (1998). Stock markets, banks, and economic growth. American Economic Review, 88, 537-558.

Michie, R. (2008). The Global Securities Market: A History. Oxford University Press.

Pankin, D. (2011). Capital Market development in Russia. Review of London Stock Exchange Conference: Russia on global markets. Retrieved from http://ondonstockexchange.com/companies-and-advisors /news-events/internationalevents/russia/russian-capital-markets-development.pdf

Vasiliev, D. (2005) Capital Market development in Russia. WB Working Paper. Retrieved from http://lnweb90.worldbank.org/eca/eca.nsf/Attachments/Vassiliev/\$File/VassilievPaper.pdf

\section{Notes}

Note 1. Russian abbreviation for Government Short Terms Obligations (GKO) and Federal Loan Bond (OFZ).

Note 2. RSM means regulated securities market.

Note 3. Professional stock market participants are legal entities, including credit institutions, as well as citizens (physical entities which are registered entrepreneurs), having a license for the following business in the securities market: broker's business, dealer's business, securities management, clearing, depositary's business, keeping the register of securities holders, settlement of trade in the securities market.

\section{Copyrights}

Copyright for this article is retained by the author(s), with first publication rights granted to the journal.

This is an open-access article distributed under the terms and conditions of the Creative Commons Attribution license (http://creativecommons.org/licenses/by/3.0/). 